University of Nebraska - Lincoln

DigitalCommons@University of Nebraska - Lincoln

Faculty Publications: Department of

Entomology

Entomology, Department of

2003

\title{
ASSESSMENT OF GRAIN YIELD LOSSES IN PEARL MILLET DUE TO THE MILLET STEMBORER, CONIESTA IGNEFUSALIS (HAMPSON)
}

\author{
Aissetou Drame-Yaye \\ Université Abdou Moumouni \\ Ousmane Youm \\ University of Nebraska-Lincoln, oyoum2@unl.edu \\ Jonathan N. Ayertey \\ University of Ghana
}

Follow this and additional works at: https://digitalcommons.unl.edu/entomologyfacpub

Part of the Entomology Commons

Drame-Yaye, Aissetou; Youm, Ousmane; and Ayertey, Jonathan N., "ASSESSMENT OF GRAIN YIELD LOSSES IN PEARL MILLET DUE TO THE MILLET STEMBORER, CONIESTA IGNEFUSALIS (HAMPSON)" (2003). Faculty Publications: Department of Entomology. 328.

https://digitalcommons.unl.edu/entomologyfacpub/328

This Article is brought to you for free and open access by the Entomology, Department of at DigitalCommons@University of Nebraska - Lincoln. It has been accepted for inclusion in Faculty Publications: Department of Entomology by an authorized administrator of DigitalCommons@University of Nebraska - Lincoln. 


\title{
Assessment of Grain Yield Losses in Pearl Millet Due to the Millet Stemborer, Coniesta ignefusalis (HAMPSON)
}

\author{
Aissetou Drame-Yaye ${ }^{1}$, Ousmane Youm $^{2}$ and Jonathan N. Ayertey ${ }^{3}$ \\ ${ }^{1}$ Faculté d'Agronomie, Université Abdou Moumouni , BP 12040 Niamey, Niger; \\ ${ }^{2}$ ICRISAT Sahelian Centre, BP 12404, Niamey, Niger; \\ ${ }^{3}$ Department of Crop Science, University of Ghana, P. O. Box LG 44, Legon Accra, Ghana
}

(Accepted 4 June 2003)

\begin{abstract}
Studies were conducted at the ICRISAT Sahelian Centre, Niger, to assess damage and yield loss by the millet stemborer, Coniesta ignefusalis (Lepidoptera: Pyralidae) on Pennisetum glaucum (L.) R. Brown. Although $78 \%$ of stems were infested, late attack by the millet stemborer on millet plants resulted in bored stems yielding more than unbored ones. Artificial infestations with 5 and 10 larvae per plant at 2 weeks after plant emergence (WAE) resulted in 50 to $70 \%$ plants with deadhearts and 24 to $100 \%$ avoidable yield loss. At 4 weeks after plant emergence, infestations with 5 larvae and 10 larvae per plant resulted in $7 \%$ increase in yield and $16 \%$ yield loss, respectively. Therefore, both the age of plant and density of borer population at the time of infestation can influence resulting stemborer damage and yield loss on pearl millet.
\end{abstract}

Key Words: Coniesta ignefusalis, stemborer, millet, Pennisetum, yield loss, West Africa

Résumé-Des études ont été menées à l'ICRISAT Centre Sahélien de Niamey au Niger pour évaluer le niveau de dégâts et les pertes de récolte causés sur Pennisetum glaucum (L.) R. Brown, par le foreur des tiges de mil, Coniesta ignefusalis (Lepidoptera: Pyralidae). Les résultats ont montré que les attaques tardives du foreur n'étaient pas préjudiciables à la production de grains, puisque dans les champs de mil où $78 \%$ des plants étaient naturellement infestés, les pieds attaqués ont produit plus de grains que les pieds sains. Les infestations artificielles deux semaines après l'apparition des plants, avec 5 et 10 larves par pied ont causé respectivement 50 et $70 \%$ de dessèchement des sommités et 24 et $100 \%$ de perte de récolte. Par contre les mêmes taux d'infestation artificielle appliqués quatre semaines après l'apparition des plants, ont donné respectivement $7 \%$ d'augmentation de récolte et $16 \%$ de perte de récolte. Par conséquent, aussi bien la période que le taux d'infestation sont importants et peuvent influencer le niveau de dégâts et les pertes de rendement dus au foreur des tiges de mil.

Mots Clés: Coniesta ignefusalis, foreur de tiges, mil, Pennisetum, perte de récolte, Afrique de l'Ouest 


\section{INTRODUCTION}

$\mathrm{P}$ earl millet, Pennisetum glaucum (L.) R. Brown is an important staple food crop in the Sahelian zone of West Africa. The millet crop is attacked by Coniesta ignefusalis Hampson (Lepidoptera: Pyralidae), a major pest in West Africa (Taneja and Nwanze, 1989), which accounts for $90 \%$ of the total stemborer population of locally improved pearl millets in Senegal (Gahukar, 1990). Early season attack by $C$. ignefusalis results in the destruction of the growing points of millet plants, resulting in premature plant death called 'deadhearts'. Attack on older plants by tunnelling larvae causes disruption of nutrient flow, stem lodging and poor or no grain formation (Harris, 1962; NRI, 1993; Youm and Gilstrap, 1993). The severity and nature of damage depends on the planting date and the time of infestation (Ajayi and Uvah, 1989; Ajayi, 1990), among other factors. Although crop damage may not always result in yield loss, Nwanze (1988), and Leuschner et al. (1985) stressed that in all yield loss studies conducted at ICRISAT, deadhearts are one of the most important factors. Yield loss assessment methods have been discussed by several authors (Chiarappa, 1981; Teng, 1987; Walker, 1981, 1983; Nwanze, 1988; Seshu Reddy, 1988; Seshu Reddy and Walker, 1990; Youm, 1990). Yield loss due to insect pests can be expressed as 'avoidable' and 'indirect' losses. Avoidable loss is best expressed as the reduction in the maximum, potential or attainable yield in the absence of the causal pest, expressed as a percentage of that attainable yield (Walker, 1983). Indirect losses are due to deadhearts and non-harvestable heads (NRI, 1993). Understanding the relationship between stemborer infestation, damage and yield losses in millet is important in determining economic threshold levels which are essential for developing efficient management strategies.

The objective of the present study was to quantify the relationship between larval infestation, damage and grain yield in millet using both artificial and natural infestations to draw recommendations for improving millet stemborer management.

\section{Materials And Methods}

\section{Trap monitoring}

Two light traps and five pheromone-baited traps similar to those described by Youm et al. (1993), and Youm and Beevor (1995), were used at ICRISAT Sahelian Centre (ISC) station. Light traps consisted of a $250 \mathrm{~W}$ mercury-vapour bulb mounted on top of a $3 \times 3 \times 3$ m screen cage with a door on one side to access and collect trapped moths. Moths caught in light traps were drawn into the cage through a plastic tube. The light bulb was switched on/off by an automatic photosensitive cell at dusk and dawn.

Water-oil pheromone traps were made of aluminum trays (32-cm diameter) filled with water to a depth of $2 \mathrm{~cm}$ and containing $17 \mathrm{ml}$ Total rubia S-40 oil (SIFAL, RCI) as a surfactant. The tray was supported at $50 \mathrm{~cm}$ above ground level on a wooden shelf $(40 \times 40 \mathrm{~cm})$ fixed to a wooden stake. Traps were baited with pheromone dispensers which consisted of polythene vials 32 by 15 by $2 \mathrm{~mm}$ thick (Agrisense-BCS) impregnated with the optimum pheromone blend prepared at the Natural Resources Institute (NRI). Pheromone traps were $300-500 \mathrm{~m}$ from the nearest light trap. Light and pheromone traps were inspected every morning to record the number of stemborer moths caught and to later monitor moth generation time and population build up. Rainfall was recorded from meteorological equipment located at the ICRISAT-Niger research station.

\section{Natural infestation}

During the 1996 rainy season, a plot was planted to the millet variety Ex-Bornou. It consisted of 29 rows, each about $29 \mathrm{~m}$ in length. Planting was done on 7 July 1996, at a spacing of $50 \mathrm{~cm}$ both inter and intra rows. Sowing, thinning and weeding were done as usual. One week after emergence (WAE), 10 hills per row were randomly sampled and tagged. Plants were selected using a table of random numbers with each random number representing the position of a hill in a given row. First date of deadheart formation was recorded by observing plants once a week starting one WAE. At harvest, the number of infested and non-infested stems per hill, and the number of harvestable and non-harvestable heads per hill were recorded for tagged hills. Harvestable heads were defined as relatively well filled with grains 
and not attacked by any diseases or by the millet head miner Heliocheilus albipunctella and any other panicles pest. Stems showing feeding galleries, entry holes or exit holes were considered as infested. Stems with harvestable heads from tagged hills, and non-infested stems with harvestable heads from the whole plot were cut from the base. Leaves and leaf sheaths of selected stems were removed and the number of internodes recorded. The numbers of entry and exit holes, and the number of larvae were counted for each internode after dissecting stems. From these data, assessments were made on infested stems and harvestable heads per hill, mean number of entry and exit holes, mean number of larvae per stem and percentage of bored internodes per stem.

Harvestable heads were stored individually in labelled bags and sun-dried for about 10 days. Each head was weighed and the net grain yield determined by weighing the harvested grains to the nearest $0.01 \mathrm{~g}$. A sample of 1000 grains was taken at random from each threshed head using an automatic grain counter and weighed to the nearest $0.01 \mathrm{~g}$. Pearson's correlation analysis was done to examine the relationship between grain weight and number of larvae per plant, grain weight and number of entry and exit holes, grain weight and percent bored internodes. Data were analysed using an analysis of variance (ANOVA) procedure using the SAS / PC package GLM (SAS Institute, 1987). Means among infested and noninfested stems were separated at a 5\% level of significance using the LSD test (SAS Institute, 1987).

\section{Artificial infestation}

The experiment was conducted in a total of 12 field cages $(9 \times 3 \times 3 \mathrm{~m})$, covered with fine meshed wire gauze to exclude other insects. The millet variety Ex-Bornu was planted in plastic pots $(16 \mathrm{~cm}$ in diameter and height) in the glasshouse and thinned to one plant per pot. One week after emergence, potted plants were transferred to the cages. Each cage contained 4 rows of potted plants with 14 pots per row. The distance between rows and between pots in a row was $60 \times 60 \mathrm{~cm}$. Cages were arranged in a completely randomised design with infestation date representing the block and replicated twice. The two infestation dates were two and four weeks after plant emergence (WAE), i.e. 17 and 23 days after sowing (DAS) respectively.
Larvae for infestation were obtained from a laboratory-reared colony. To optimise larval establishment, plants were artificially infested after about $1800 \mathrm{~h}$. Neonate larvae were transferred to plants using a soft camelhair brush. Treatments consisting of control (no infestation), 5 and 10 larvae per plant, corresponding to densities of 0,280 and 560 larvae per cage respectively, were randomly assigned to blocks in each of the two replications. The number of hills and plants showing deadhearts were counted for three consecutive weeks after infestation, starting from week one. The percentage deadhearts was estimated as the number of hills or plants with deadhearts over the total number of hills or plants. At harvest, the total number of harvestable and non-harvestable heads per hill were counted. Stems with harvestable heads were cut and brought to the laboratory where they were placed individually in labelled bags and sun-dried for about 10 days. Yield was evaluated by weighing threshed grains to the nearest $0.01 \mathrm{~g}$. Percent avoidable loss in yield ( $\mathrm{w} \%$ ) was calculated using the formula reported by Walker (1983): $w \%=(m-$ $y) / m \times 100$, where $m=$ yield obtained in control plots and $y=$ yield obtained in a particular treatment.

Means were computed using the general linear model procedure (Proc GLM SAS Institute, 1987) and separated at 5\% level of significance using least significant difference (LSD) test (SAS Institute, 1987). Means between the two infestation dates were compared using a t-test $(\mathrm{P}$ $=0.05)$. Before analysis, percentages were subjected to arcsine square root transformations.

\section{Results}

\section{Trap monitoring}

First adults were caught in traps in mid-June (Fig. 1), two weeks after the first rain of 31 May. During the study period, three generations of moths of unequal sizes could be distinguished from both light and pheromone trap catches. The first generation lasted about seven weeks. It started in mid June and showed the smallest peak. The second generation had the highest peak. It begun in the second week of August and lasted about seven weeks. The third generation moth, intermediate in size, occurred from mid September to almost the end of November. First 


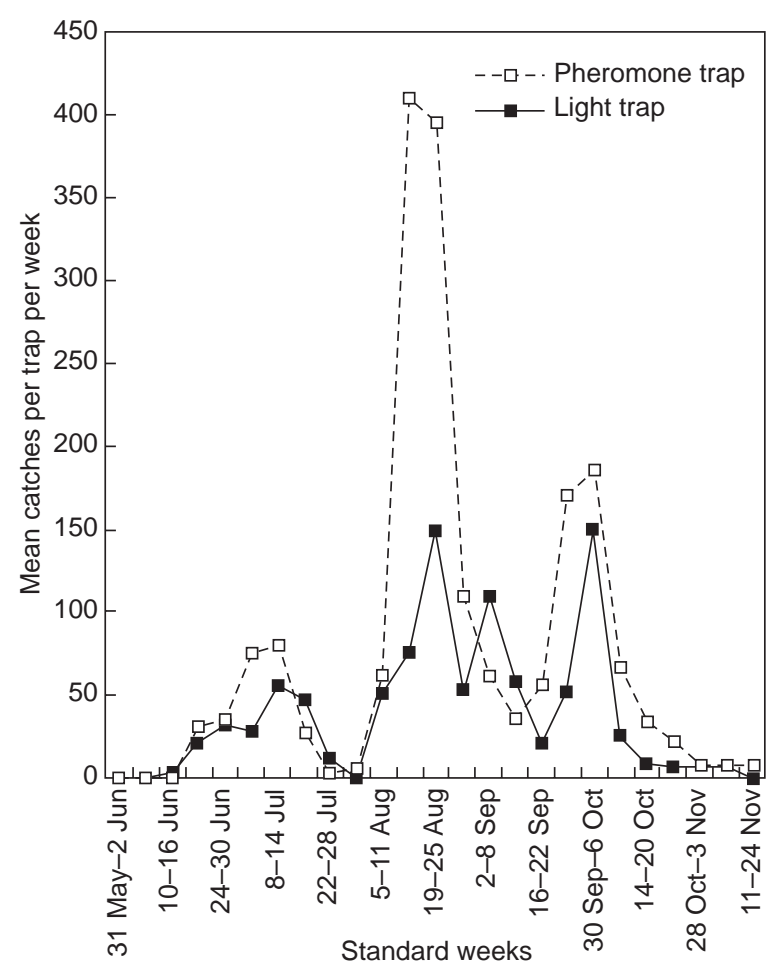

Fig. 1. Pheromone and light trap catches of millet stemborer adults at ICRISAT Niamey in 1996

and second generations peaked around three weeks after their first moths appeared, while the third generation peaked two weeks after moth apparition.

\section{Natural infestation}

The first deadhearts were observed on plants at 5 weeks after plant emergence (about mid August). At harvest, the total number of plants per hill ranged from 1 to 10 , with a mean of 3.41 and an average of 2.73 infested by C. ignefusalis. There was an average of 0.41 harvestable heads per hill, corresponding to $16.18 \pm 1.62 \%$ of the total produced heads per hill. The mean percentage of infested stems was $78 \%$.

A mean number of 20 entry holes was counted per infested stem but only 3 exit holes and 4 larvae were collected per stem (Table 1). Although there was no significant difference in thousand-grain weight between infested and non-infested stems, net grain yield per stem was significantly higher for infested stems. The net grain yield increase in infested stems than in the uninfested stems was $26.48 \%$. This increase in yield in infested stems could be due to several reasons (refer to
Discussion) such as rapid plant compensation to borer attack, a better growth stimulation due to attack, the choice of females to lay eggs on more vigorous plants etc. The thousand-grain weight of infested stems was negatively correlated with number of entry holes $(r=-0.23, P=0.04)$ (Table 2$)$.

\section{Artificial infestation}

More than $90 \%$ of the hills infested at 2 WAE had deadhearts, against less than $50 \%$ for infestations at 4 WAE (Table 3). Early attacks resulted also in 50-70\% plants with deadhearts, while infestations at $4 \mathrm{WAE}$ resulted in 16 to $25 \%$ plants with deadhearts. Harvestable heads and grain per head were significantly heavier in cages infested at 4 weeks after plant emergence (WAE) than at 2 WAE (Table 4). Subsequently, cages infested at 4 WAE yielded more than those infested at 2 WAE. No harvestable heads were obtained in cages infested at 2 WAE with 10 larvae per plant. Within infestation dates, treatments with 0 and 5 larvae per plant did not show significant differences in the weight of their harvestable heads, while 10 larvae per plant gave significantly lower weight. In cages infested at $2 \mathrm{WAE}$, grain weight per head was not significantly different between treatments with 0 and 5 larvae per plant. Infestations at 4 WAE gave significantly higher grain weight in control cages (0 larva per plant) and significantly lower in cages with 10 larvae per plant. However, there was no significant difference in grain weight per head between treatments with 5 and 10 larvae per plant. At 2 WAE, $24.07 \%$ and $100 \%$ avoidable yield loss was calculated from cages with 5 and 10 larvae per plant, respectively. Infestation at $4 \mathrm{WAE}$ gave a negative avoidable yield loss of $-7.94 \%$ for 5 larvae per plant, and $15.49 \%$ for 10 larvae per plant. Thus, both the age of plant and density of borer population at the time of infestation can influence resulting stemborer damage and yield loss on pearl millet.

\section{Discussion}

There was a two-week lag time between first moth catches and the first rain. This time was necessary for diapausing larvae inside old millet stems to pupate and emerge as adults. The number of adults caught varied with millet phenology. The first generation moths had the smallest peak because it appeared at the beginning of the rainy season when planting had just started in millet 
Table 1. Damage on stems and grain yield at harvest of pearl millet following natural infestation by Coniesta ignefusalis

\begin{tabular}{lccccccc}
\hline & \multicolumn{7}{c}{ Mean \pm SE per stem } \\
\cline { 2 - 7 } & Height $(\mathrm{cm})$ & $\begin{array}{c}\text { Number } \\
\text { of entry } \\
\text { holes }\end{array}$ & $\begin{array}{c}\text { Number } \\
\text { of exit } \\
\text { holes }\end{array}$ & $\begin{array}{c}\text { Bored } \\
\text { internodes } \\
(\%)\end{array}$ & $\begin{array}{c}\text { Number of } \\
\text { larvae/stem }\end{array}$ & $\begin{array}{c}\text { Net grain } \\
\text { yield }(\mathrm{g})\end{array}$ & $\begin{array}{c}1000 \text {-grain } \\
\text { weight }(\mathrm{g})\end{array}$ \\
\hline Infested & $212.09 \pm 3.1 \mathrm{a}$ & $20.08 \pm 2.01$ & $3.14 \pm 0.4$ & $42.87 \pm 2.81$ & $4.09 \pm 0.43$ & $29.33 \pm 1.23 \mathrm{a}$ & $7.62 \pm 0.2 \mathrm{a}$ \\
Non-infested & $194.99 \pm 5.92 \mathrm{~b}$ & - & - & - & - & $23.19 \pm 2 \mathrm{~b}$ & $7.03 \pm 0.3 \mathrm{a}$ \\
\hline
\end{tabular}

Average percent infested stems $=78.41 \pm 1.76 \%$. Average percent harvestable heads per hill $=16.18 \pm 1.62 \%$.

Means in the same column followed by the same letter are not significantly different at $\mathrm{P}=0.05$ (LSD test).

Table 2. Correlations between Coniesta ignefusalis damage (percent bored internode, number of larvae, entry and exit holes) and grain weight in naturally infested plots

\begin{tabular}{lll}
\hline Parameters & \multicolumn{1}{c}{$\begin{array}{c}\text { Net grain } \\
\text { weight }^{1}\end{array}$} & \multicolumn{1}{c}{$\begin{array}{c}\text { Thousand } \\
\text { grain weight }^{2}\end{array}$} \\
\hline \% bored internodes & $0.06(\mathrm{P}=0.59) \mathrm{NS}$ & $-0.20(\mathrm{P}=0.07) \mathrm{NS}$ \\
No. of entry holes & $0.05(\mathrm{P}=0.64) \mathrm{NS}$ & $-0.23(\mathrm{P}=0.04) \mathrm{S}$ \\
No. of exit holes & $0.19(\mathrm{P}=0.07) \mathrm{NS}$ & $-0.10(\mathrm{P}=0.38) \mathrm{NS}$ \\
No. of larvae & $0.21(\mathrm{P}=0.06) \mathrm{NS}$ & $-0.14(\mathrm{P}=0.22) \mathrm{NS}$ \\
\hline
\end{tabular}

$1_{\mathrm{n}}=89$.

$2 \mathrm{n}=86$.

NS = not significant; $\mathrm{S}=$ significant.

Table 3. Percentages of deadhearts from artificially infested caged plants at two infestation dates

\begin{tabular}{|c|c|c|c|c|c|c|}
\hline \multirow{3}{*}{$\begin{array}{l}\text { No. of } \\
\text { larvae/ } \\
\text { plant }\end{array}$} & \multicolumn{6}{|c|}{ Infestation dates } \\
\hline & \multicolumn{3}{|c|}{ Two weeks after plant emergence (2 WAE) } & \multicolumn{3}{|c|}{ Four weeks after plant emergence (4 WAE) } \\
\hline & $\begin{array}{c}\text { Hills with } \\
\text { deadheart }(\%)\end{array}$ & $\begin{array}{l}\text { Hills with } \\
\text { all plants dead }(\%)\end{array}$ & $\begin{array}{c}\text { Plant with } \\
\text { deadheart }(\%)\end{array}$ & $\begin{array}{c}\text { Hills with } \\
\text { deadheart }(\%)\end{array}$ & $\begin{array}{l}\text { Hills with } \\
\text { all plants dead }(\%)\end{array}$ & $\begin{array}{c}\text { Plants with } \\
\text { deadheart }(\%)\end{array}$ \\
\hline 0 & 0 & 0 & 0 & 0 & 0 & 0 \\
\hline 5 & 94.5 & 10.81 & 50.25 & 16.84 & 0 & 16.66 \\
\hline 10 & 99.08 & 51.35 & 71.96 & 43.54 & 0 & 25 \\
\hline
\end{tabular}

fields. The second generation, with more moths caught, coincided with the period when the millet was fully-grown. The rate of $C$. ignefusalis natural infestation was $78.41 \%$. Field surveys conducted from 1980-1983 in different regions in Burkina Faso and Niger found from 44.6 to $72 \%$ infested stems in Burkina Faso and 35.2 to $69.1 \%$ in Niger (Nwanze, 1988). Despite the high infestation level, infested stems yielded more than non-infested ones, indicating that infestations occurred late and on more vigorous plants. Harris (1962) reported that many crop loss assessments based on counts of percentage bored stems showed that correlation of these counts with yield sometimes fails to demonstrate any reduction in yield and may even show that highly attacked plants yield more. In
Nigeria, Harris (1962) assessed yields of bored and unbored early millet stems. He found that bored stems yielded less than unbored stems in three cases and more in two cases. He also noticed that in the latter case borer attack was associated with better plant growth and hence higher yields. Flattery (1982), while estimating Chilo partellus (Swinhoe) damage on grain sorghum in Botswana, explained the increase in yield of bored stems by the selective infestation of stronger plants. At ICRISAT, it was found that $60 \%$ tunnelling by $C$. partellus in any part of the stem did not reduce the grain yield of the susceptible sorghum variety CSH1 (Taneja and Leuschner, 1985). The low effect of borer attack on yield might also result from good plant growth conditions. Stemborer 
infestations associated with better plant growth was reported by Setamou et al. (1993), who showed that nitrogen fertiliser not only increased yields but also survival and, thus, final densities of $S$. calamistis on maize. Increase in yield may also result in attack having a growth hormonal effect (Walker, 1983).

Young plants artificially infested were more sensitive to deadheart formation than older ones. Similar results were obtained earlier by Taneja and Nwanze (1989) who showed by artificially infesting resistant and susceptible sorghum genotypes with $0,4,8$ and 12 larvae per plant at $15,20,30,40$ and 50 days after emergence (DAE), that early infestation (at 15 days after plant emergence) resulted in maximum damage and yield reduction than infestation at 30 days after emergence for both genotypes. Seshu Reddy and Sum (1991) studied the relationship between Chilo partellus infestation and grain yield under artificial infestations. They found that grain yield loss was higher in the young plants (21 DAE) when subjected to the same kind of treatment than older stages, irrespective of cultivars and larval densities. Seshu Reddy (1988) reported on studies conducted at the ICIPE's field station in western Kenya, where C. partellus caused $74.4 \%$ grain yield losses when plants were artificially infested with 5 larvae per plant at $10 \mathrm{DAE} ; 87.8 \%$ when plants were infested with 10 larvae at 10 DAE and 2$13 \%$ at $60 \mathrm{DAE}$. The high avoidable yield loss in cages infested at 2 WAE was attributable to the development in the same cages of successive generations of the MSB which always attack the young new tillers formed from the same hills. Plants infested at 4 WAE were strong enough to support new infestations without significant losses.

The present study supports results reported by other authors on the stemborer species, that early infestations result in maximum damage and yield loss than late infestations, and that yield loss in late infestations is not always correlated with the intensity of damage. For pest resistance programmes or economic injury level studies, artificial infestation levels of more than 5 larvae per plant at 2 WAE should be used.

Acknowledgements - We gratefully acknowledge Winrock International and the International Institute of Tropical Agriculture (IITA) through the African Women Leaders in Agriculture and 
Environment (AWLAE) programme, for providing the scholarship. We are gratefull to The IFAD TAG \# 442 support for Visiting Scientist. We thank Maliki Yacouba, Idi Saley, Salha Halarou, Amadou Kangueye, Moussa Mamoudou and the technical staff in the Entomology Unit, ICRISAT Sahelian Centre, Niamey, for their help during the course of study.

\section{REFERENCES}

Ajayi O. (1990) Possibilities for integrated control of the millet stem borer Acigona ignefusalis Hampson (Lepidoptera: Pyralidae) in Nigeria. Insect Sci. Applic. 11, 109-117.

Ajayi O. and Uvah I. I. (1989) Review of research on millet entomology in Nigeria. In Regional Pearl Millet Workshop, ICRISAT-IAR/ABU Samaru, Zaria, Nigeria, 15-19 Aug. 1988. IAR, Ahmadu Bello University, Zaria, Nigeria and International Crops Research Institute for the Semi-Arid Tropics (ICRISAT), Patancheru, India. $10 \mathrm{pp}$.

Chiarappa L. (Ed.) (1981) Crop Loss Assessment Methods. Supplement 3. Rome, FAO, 123 pp.

Flattery K. E. (1982) An assessment of pest damage on grain sorghum in Botswana. Exp. Agric. 18, 319-328.

Gahukar R. T. (1990) Population ecology of Acigona ignefusalis Hampson (Lepidoptera: Pyralidae) in Senegal. Environ. Entomol. 19, 13-19.

Harris K. M. (1962) Lepidopterous stem borers of cereals in Nigeria. Bull. Entomol. Res. 53, 139-171.

Leuschner K., Taneja S. L. and Sharma H. C. (1985) The role of host plant resistance in pest management in sorghum in India. Insect Sci. Applic. 6, 453-460.

Natural Resources Institute (NRI) (1993) Millet croploss assessment methods. Bulletin 62. NRI, UK.

Nwanze K. F. (1988) Assessment of on-farm losses in millets due to insect pests. Insect Sci. Applic. 9, 673677.

SAS Institute (1987) User's Guide: Statistics. SAS Institute, Cary, N.C.

Seshu Reddy K. V. (1988) Assessment of on farm yield loss in sorghum due to insect pests. Insect Sci. Applic. 9, 679-685.

Seshu Reddy K. V. and Sum K. O. S. (1991) Determination of economic injury level of the stem borer, Chilo partellus (Swinhoe) in maize, Zea mays L. Insect Sci. Applic. 12, 269-274.

Seshu Reddy K.V. and Walker P. T. (1990) A review of the yield losses in graminaceous crops caused by Chilo spp. Insect Sci. Applic. 11, 563-569.
Setamou M., Schulthess F., Bosque-Perez N. A. and Odjo T. (1993) The effects of plant nitrogen and silica on the bionomics of Sesamia calamistis (Lepidoptera: Noctuidae). Bull. Entomol. Res. 83, 405-411.

Taneja S. L. and Leuschner K. (1985) Methods of rearing, infestation and evaluation for Chilo partellus resistance in sorghum, pp. 175-188. In Proceedings of the International Sorghum Entomology Workshop, 15-21 July 1984, Texa A\&M University, College Station, Texas, USA. International Crops Research Institute for the Semi-Arid Tropics, Patancheru, India.

Taneja S. L. and Nwanze K. F. (1989) Assessment of yield loss of sorghum and pearl millet due to stem borer damage. In International Workshop on Sorghum Stem Borers, ICRISAT (International Crops Research Institute for the Semi-Arid Tropics), 17-20 Nov. 1987. International Crops Research Institute for the Semi-Arid Tropics, Patancheru, India. 6 pp.

Teng P. S. (Ed.) (1987) Crop loss assessment and pest management. The American Phytopathol. Soc. 270 pp. APS Press.

Walker P. T. (1981) The relation between infestation by lepidopterous stem borers and yield in maize: Methods and results. Eppo bulletin 11, 101-106.

Walker P. T. (1983) Crop losses: The need to quantify the effects of pests, diseases, and weeds on agricultural production. Agric. Ecosyst. Environ. 9, 119-158.

Youm O. (1990) Evaluation of natural enemies associated with the millet stalk borer Hambachia ignefusalis (Hampson) (Lepidoptera: Pyralidae) in Niger. 145 pp. PhD dissertation, Texas A \& M University, College Station, Texas, USA.

Youm O. and Beevor P. S. (1995) Field evaluation of pheromone-baited traps for Coniesta ignefusalis (Lepidoptera: Pyralidae) in Niger. J. Econ. Entomol. 88, 65-69.

Youm O. and Gilstrap F. E. (1993) A note on the bioecology of the millet stem borer Coniesta (=Haimbachia) ignefusalis (Lepidoptera: Pyralidae) in Niger. Samaru J. Agric. Res. 10, 97-104.

Youm O., Mamalo A. K. and Nwanze K. F. (1993) Bioecology and integrated management of the millet stem borer (Lepidoptera: Pyralidae): A review and current research at the ICRISAT Sahelian Centre, pp. 55--63. In Proceedings of the Regional Pearl Millet Workshop, 19-21 September, 1990 (Edited by O. Youm and K. A. Kumar). ICRISAT Sahelian Centre, BP 12404, Niamey, Niger. Pearl Millet Improvement Program, ICRISAT Sahelian Center, International Crops Research Institute for the Semi-Arid Tropics. 